\title{
ON ENTOSTHODON FASCICULARIS AND WEISSIA ARMATA COMB. NOV. (=W. PAPILLOSISSIMA LAZ.) IN RUSSIA
}

\author{
ОБ ENTOSTHODON FASCICULARIS И WEISSIA ARMATA COMB. NOV. \\ (=W. PAPILLOSISSIMA LAZ.) В РОССИИ \\ VLADIMIR E. FEDOSOV ${ }^{1}$ \\ ВЛАДИМИР Э. ФЕДОСОВ ${ }^{1}$
}

\begin{abstract}
Entosthodon fascicularis (Hedw.) Müll.Hal., previously excluded from the Russian moss flora, was recently found in the foothill part of limestone area of Dagestan (Eastern Caucasus, Russia). Weissia armata (Thér. \& Trab.) Fedosov comb. nov. ( $=W$. papillosissima Laz.), the species, unknown in Russia before, was also found not far from this locality in Inner Dagestan. Descriptions and illustrations based on specimens from Russia are provided, ecology and distribution of these species are observed.

Резюме

Entosthodon fascicularis (Hedw.) Müll.Hal., ранее исключённый из флоры России, был недавно обнаружен в предгорной части известнякового Дагестана (Восточный Кавказ). Weissia armata (Thér. \& Trab.) Fedosov comb. nov. (=Weissia papillosissima Laz.) была выявлена в том же регионе. Приводятся описания и иллюстрации растений по российским образцам. Обсуждается экология и распространение этих видов.
\end{abstract}

KEYWORDS: Dagestan, Entosthodon, Weissia, Funariaceae, Pottiaceae, xeric species, rare moss species

Recent bryological exploration of Dagestan Republic (the East Caucasus) has provided rich collections of xeric mosses, including some species new for Russia and for science (Ignatov et al., 2010, Fedosov et al., 2010, Fedosov \& Ignatova, 2010, Fedosov, 2010). Further research of the Dagestan limestone area reveales additional interesting records, including two species new for Russia, Entosthodon fascicularis and Weissia armata. The first of them has been recently excluded from the Russian moss flora (Fedosov et al., 2010) because all its previous records were based on misidentified specimens of other species, mostly E. handelii (Schiffn.) Laz. However, in 2011 it was collected in Buinaksk District of Dagestan Republic.
Entosthodon fascicularis (Hedw.) Müll. Hal. (Gymnostomum fasciculare Hedw., Funaria fascicularis (Hedw.) Lindb.)

Figs. 1-3

Plants in loose low tufts or intermixed with other mosses, green to whitish, more or less discolored with age; stem 4-7 mm. Leaves mostly crowded near apex, near stem base 1-2 leaves \pm distant, small; upper leaves larger, appressed to somewhat spreading when dry, spreading when moist, ovate or ovate-lanceolate, (2.0-)2.2$2.8(-2.9) \times(0.7-) 0.9-1.2(-1.3) \mathrm{mm}$, more or less strongly concave, shortly acuminate; margins entire proximally, usually crenulate in mid-leaf, and serrulate distally; costa weak, green to brownish, subpercurrent; upper and median laminal cells thin-walled, irregularly elongate-hexagonal,

${ }^{1}$ - Moscow State University, Biological Faculty, Geobotany Dept., Moscow 119991 Russia - Poccия 119991,
Москва, Московский университет, Биологический факультет, каф. геоботаники; e-mail: fedosov_v@ mail.ru 
short rectangular or rhomboidal, (38-)50-67(-72) $\times 19-28 \mu \mathrm{m}$, basal laminal cells longer, rectangular, (75-) 90-145(-160) $\times 20-30 \mu \mathrm{m}$, alar cells thinwalled, distinctly shorter and broader than basal juxtacostal cells, forming small, flat or slightly inflated convex auricles; leaf border undifferentiated in leaf base or throughout or unclearly differentiated in 1 row, composed of narrow yellowish cells $(60-) 72-85(-90) \times 12-15(-19) \mu \mathrm{m}$, with oblique transverse walls and extremely thin outer walls. Synoicous. Seta 0.9-1.2 cm, straight, yellow or reddish to brownish. Capsule yellowish to brownish, erect, straight, symmetric, elongate-pyriform, 1.5-2.2 mm, with neck \pm differentiated, shorter or equal with urn, narrowed at mouth or widened after spore release; exothecial cells in middle part of capsule isodiametric, $15-36 \times 20-28 \mu \mathrm{m}$, quadrate, short rectangular to transversely rectangular, somewhat rounded, thin-walled, irregularly arranged due to numerous stomata; annulus not differentiated; peristome strongly reduced, represented by a membrane slightly protruding over mouth. Operculum plane-convex. Calyptra cucullate. Spores 21-36 $\mu \mathrm{m}$, brownish, papillose.

Specimens examined: RUSSIA, Dagestan Republic, Buinaksk District, vicinity of Talgi Settlement (ca. $10 \mathrm{~km} \mathrm{SSW}$ from Mahachkala), Talgi Canyon, $42^{\circ} 52^{\prime} 39^{\prime \prime} \mathrm{N}-47^{\circ} 27^{\prime} 22^{\prime \prime} \mathrm{E}, 530 \mathrm{~m}$ alt., 5.VI.2011, $\mathrm{Fe}$ dosov \#\# 11-1-6, 11-1-7 (MW). S+.

Ecology. Entosthodon fascicularis was found on the upper part of a hollow slope with steppe vegetation. The species was most abundant in the place, apparently disturbed by fire, with open grass cover and a relatively well-developed moss carpet, mostly of Weissia sp., Tortella sp., Didymodon sp., Ceratodon purpureus, Bryum argenteum, etc.

Distribution. Entosthodon fascicularis is mainly restricted to Ancient Mediterranean and Madrean floristic regions, penetrating into adjacent regions with humid climate along western coasts of continents (Fig. 7). It is known from most European countries from Azores and Canary Islands to Lithuania, Latvia, Ukraine, and from Scandinavian countries to Mediterranean islands (Corsica, Sicilia, Sardinia, Cyprus), North Africa (Egypt, Lybia), Turkey, Arabian Peninsula and Socotra Island, Iran, Middle Asia (Kazakhstan, Tajikistan), Canada (British Columbia), USA (Idaho, Washington, Oregon, California,
Arizona) (Akhani \& Kurschner, 2004; Erzberger \& Papp, 2004; Kürschner, 2003; Kürschner \& Erdag, 2005; Lloret \& González-Mancebo, 2011; Miller \& Miller 2007; Pocs et al., 2002; Sabovljević et al., 2008; Sérgio et al., 2006; Sotiaux et al., 2007; Smith, 1978).

Species distinction. The combination of a symmetric capsule with a short neck and short rectangular exothecial cells delimit E. fascicularis from all other Entosthodon species known in Russia. Brugués \& Ruiz (2010) provide the description of one more species with this combination of features, E. mouretii (Corb.) Jelenc., which differs from E. fascicularis in nerve filling the leaf apiculus vs. ending shortly below apex. In our specimen this character is however variable.

Weissia armata (Thér. \& Trab.) Fedosov comb. nov. - Trichostomum armatum Thér. \& Trab., Bull. Soc. Hist. Nat. Afrique N. 22: 160. f. 2. 1931. Figs. 4-6

Weissia papillosissima Laz., Dopov. Akad. Nauk Ukrajins'k. RSR 1967: 752. f. 1. 1967.

Plants small, in compact tufts, green, olivaceous-green, \pm whitish. Stem 3-5 mm, weakly branched. Leaves crisped when dry, spreading when moist, (1.0-)1.2-1.6(-1.8) $\times(0.28-) 0.32$ $0.38(-0.40) \mathrm{mm}$, lanceolate, linear-lanceolate, obtuse to acute at apex; costa green, strong, 50-95 $\mu \mathrm{m}$ wide at base, occupying 1/6-1/4 of leaf base width, moderately tapering to leaf apex, excurrent into short stout brownish acumen, smooth dorsally, papillose on ventral surface, in transverse section with two stereid bands, dorsal epidermis not differentiated; lamina unistratose, margins broadly and strongly (up to $360^{\circ}$ ) involute distally, entire to slightly crenulate due to protruding papillae; median laminal cells isodiametric, thin-walled, subquadrate, rounded-hexagonal to almost hexagonal, 7-11 $\times 7-9 \mu \mathrm{m}$, arranged in \pm regular longitudinal rows, with 1-2(-4) large, strongly forked papillae per cell, elevated on mamilla-like protruding cell surfaces on both dorsal and ventral sides; basal laminal cells greenish, rectangular, 12-20×6$12 \mu \mathrm{m}$, with moderately thickened walls, smooth, translucent, basal marginal cells discolored, thinwalled. Sporophytes unknown from Russia. [Apparently paroicous. Seta yellowish, 3.3-3.7 mm 


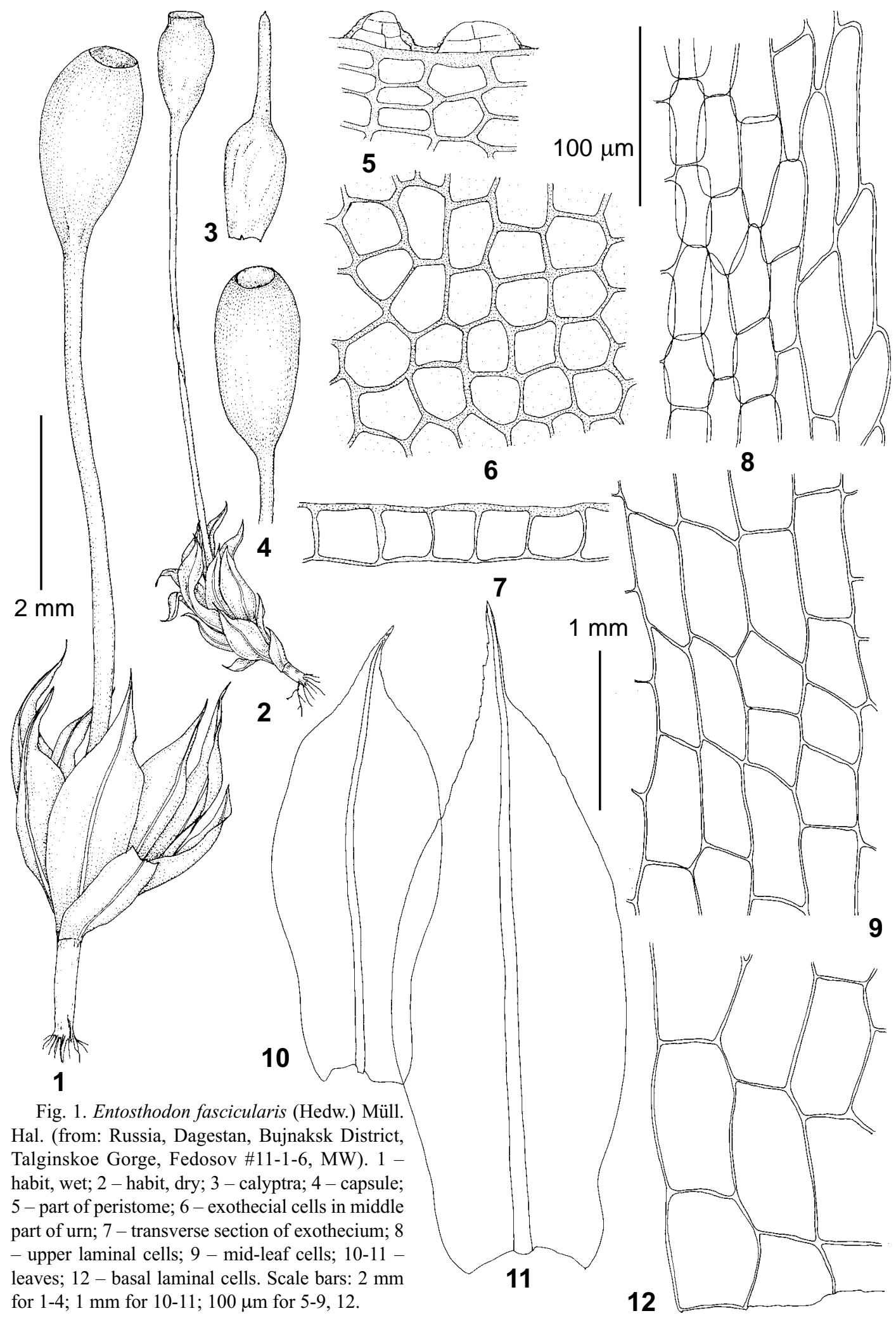





Figs. 2-3: Entosthodon fascicularis (Hedw.) Müll. Hal. (from: Russia, Dagestan, Fedosov \#11-1-6, MW); 4: Weissia condensa (Voit.) Lindb. (from: Russia, Altai Mts, 24.VI.1991, Ignatov, MW); 5: W. armata (from: Russia, Dagestan, Fedosov \#11-1-2, MW). 1 - capsule mouth showing strongly rudimentary peristome; 2 spore; 3-4 - papillae on leaf surface. All scale bars $10 \mu \mathrm{m}$.

long; capsule dull brown, exerted, erect, ellipsoid, 1.3-1.4×0.7 mm, striate when dry, annulus poorly differentiated, mouth of the capsule closed by an epiphragm; peristome 1acking, lid longly rostrate, with oblique beak $0.55-0.59 \mathrm{~mm}$ long; calyptra yellow, longly cucullate. Spores dull brown, isodiametric, with dense perinous pattern of granular elements, sometimes slightly anastomosed, $12-16 \mu \mathrm{m}$ in diameter; the ornamentation is, therefore, not much different from that of many Pottiaceae (Moya et al., 1995)].

Specimen examined: RUSSIA: Dagestan Republic, Lewashi Distr., vicinity of Gubden Settl. $\left(42^{\circ} 35^{\prime} \mathrm{N}-\right.$ 4708'E), ca. 900 m. alt., 6.VI.2011, Fedosov \#11-1-2 (MW).

Studied specimens of Weissia condensa: AUSTRIA: E. Bauer, Musci europaei exsiccati \#256 (MW); UKRAINE: Crimea, 25.VI.1962, Kurchenko (MW);
RUSSIA: Caucasus, Teberda Nature Reserve, Ignatov \& Ignatova 05-1240, 05-3169, 05-3708, 05-1087,053309 (MW); Altai Mts., 24.VI.1991, Ignatov (MW).

Ecology. In Dagestan Republic, Weissia armata was found growing with Fissidens bryoides Hedw. on calcareous fine soil covering a limestone boulder in the canyon bottom. This species was considered to be a calciphilous one, growing on dry slopes under schrub and grass canopy (Moya et al., 1995, Cano et al., 2002). Specimen from Tajikistan (LE) cited by Moya et al. (1995) was collected at ca. $1650 \mathrm{~m}$ alt., while in Dagestan and Iberian Peninsula it occurs mostly in altitudinal range 800-1100 m.

Distribution. Weissia armata is a rare species with distribution closely associated with the Ancient Mediterranean region (Fig. 7), including 


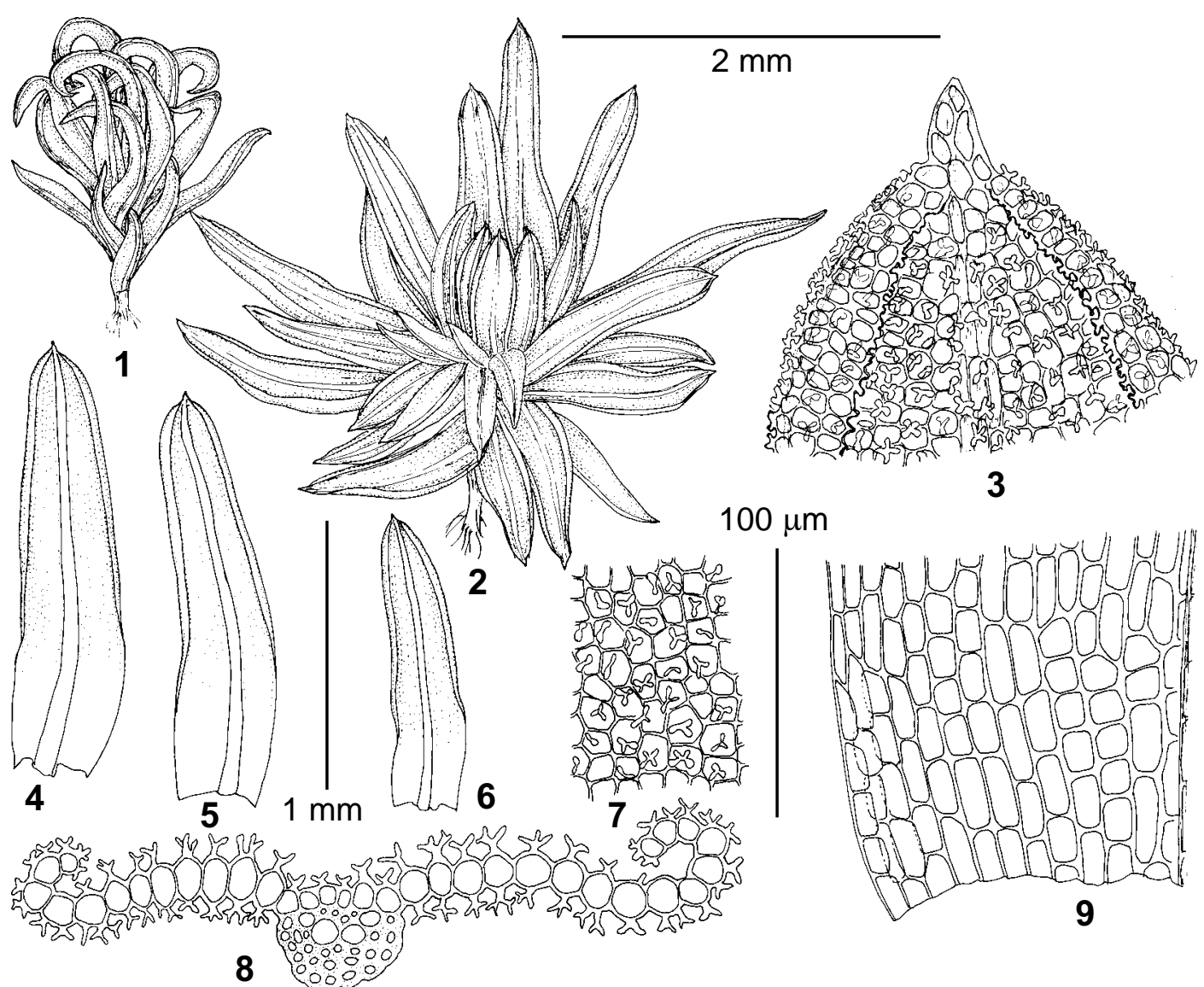

Fig. 6. Weissia armata (Thér. \& Trab.) Fedosov (from: Russia, Dagestan, Levashi District, vicinity of Gubden, Fedosov \#11-1-2, MW). 1 - habit, dry; 2 - habit - wet; 3 - cells of apical part of leaf; 4-6 - leaves; 7 - mid-leaf cells; 8 - leaf transverse section; 9 - basal laminal cells. Scale bars: $2 \mathrm{~mm}$ for 1-2; $1 \mathrm{~mm}$ for 4-6; $100 \mu \mathrm{m}$ for 3, 7-9.

Portugal, Spain, Algeria, Morocco, Balearic Islands, Turkey, Turkmenia, Tajikistan (Cano et al., 2000, 2002, 2004; Ignatov, Afonina, Ignatova et al., 2006; Keceli et al, 2011; Meier, 2008; Sergio \& Carvalho, 2003).

Species distinction and taxonomy. Due to relatively short lanceolate leaves with mostly obtuse apices and strongly involute margins, $W$. armata resembles $W$. condensa, but high (ca. 10 $\mu \mathrm{m})$ strongly forked papillae differ it from any other Weissia species.

Russian taxonomic literature treated this species as Weissia papillosissima Laz., the species described from Tajikistan, and also reported from Turkmenistan (Ignatov, Afonina, Ignatova et al., 2006) and Spain (Moya et al., 1995). Cano et al. (2002) found its identity with North African Trichostomum crispulum var. armatum, suggesting a new combination, $W$. condensa var. armata (Thér. \& Trab.) Cano, Ros \& J. Guerra. However, the recent molecular data (Werner et al., 2005) do not support the position of "var. armata" within Weissia condensa, and the morphological difference seems to be stable enough for recognition of this taxon as a separate species.

In addition to high papillae $W$. armata differs from $W$. condensa in shorter leaves, (1.0-)1.2$1.6(-1.8) \mathrm{mm}$ (vs. 1.8-2.4 $\mathrm{mm}$ in $W$. condensa), which are also less incurved as compared to the latter species.

\section{ACKNOWLEDGEMNETS}

I am grateful to Ramazan Murtazaliev for field work arrangement and to Elena Ignatova for confirmation of specimen identification, comments on the manuscipt and preparing illustrations. The work was partly supported by the Federal Program «Sci- 


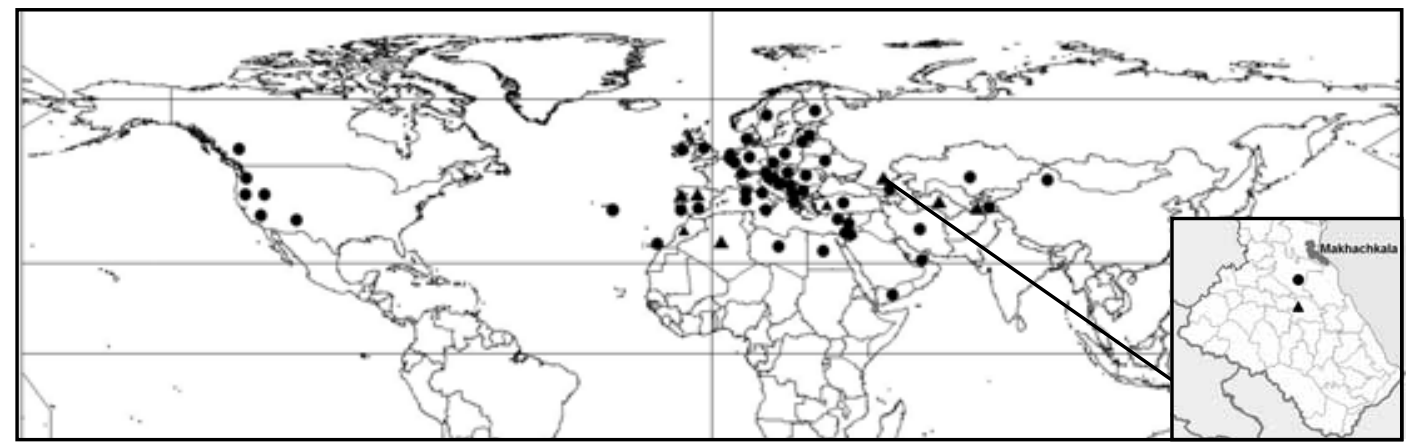

Fig. 7. World distribution of Entosthodon fascicularis (soild circles) and Weissia armata (triangles). Mapping to country/ state level.

entific and Educational personalities of innovative Russia, 2009-2013» (№№ 16.740.11.0680, 14.740.11.0165 \& 16.740.11.0177).

\section{LITERATURE CITED}

AKHANI, H. \& H. KÜRSCHNER 2004. An annotated and updated check-list of the Iranian bryoflora. - Cryptogamie, Bryologie 25: 315-347.

BRUGUÉS, M. \& E. RUIZ 2010. Entosthodon. - In: Flora Briofitica Ibérica. Vol. 4, Murcia, Univ. Murcia, Soc. Bryol. Espańola: 44-59.

CANO, M.J., J.A. JIMÉNES, M.T. GALLEGO, R.M. ROS \& J. GUERRA 2004. Bryophyte Check-list of Murcia Province (Southeastern Spain). - Anales de Biología 26: 117-155.

CANO, M.J., R.M. ROS, M.T. GALLEGO, J.A. JIMÉNES \& J. GUERRA 2002. Contribution to the bryophyte flora of Morocco: the Anti-Atlas catalogue. - Criptogamie, Briologie 23(1): 249-262.

CANO, M.J., R.M. ROS \& J. GUERRA 2000. Identity of North African endemic bryophytes. I. - J. Bryol. 22: 269-272.

ERZBERGER, P. \& B. PAPP 2004. Annotated check-list of Hungarian bryophytes. - Studia Bot. Hung. 35: 91-149.

FEDOSOV, V.E. 2010. Aloina bifrons (De Not.) Delgad. (Pottiaceae, Musci) in Russia. - Arctoa 19: 233-238.

FEDOSOV, V.E. \& E.A. IGNATOVA 2010. Orthotrichum dagestanicum sp. nov. (Orthotrichaceae, Musci) - a new species from Dagestan (East Caucasus). - Arctoa 19: 69-74.

FEDOSOV, V.E., E.A. IGNATOVA, M.S. IGNATOV \& G.Ya. DOROSHINA 2010. On the genus Entosthodon (Funariaceae, Musci) in the Caucasus. - Arctoa 19: 75-86.

IGNATOV, M.S., O.M. AFONINA, E.A. IGNATOVA et al. 2006. Check-list of mosses of East Europe and North Asia.Arctoa 15: 1-130.

IGNATOV, M.S., V.E. FEDOSOV, E.A. IGNATOVA \& G.Ya. DOROSHINA 2010. Moss flora of Gunib area in Dagestan (East Caucasus). - Arctoa 19: 87-96.

KECELI, T., S. URSAVAS \& G. ABAY 2011. The bryophyte check-list for B6 Square of Turkey. - Bartýn Orman Fakültesi Dergis 13 (19): 14-24.

KÜRSCHNER, H. 2003. Nineteen new records to the bryophyte flora of Socotra Island. Additions to the bryophyte flora of the Arabian Peninsula and Socotra. 5. - Willdenowia 33: 445-458.

KÜRSCHNER, H. \& A. ERDAG 2005. Bryophytes of Turkey: an annotated reference list of the species with synonyms from the recent titerature and an annotated list of Turkish bryological literature. - Turk. J. Bot. 29: 95-154.

LLORET, F. \& J.M. GOZÁLES-MANCEBO 2011. Altitudinal distribution patterns of bryophytes in the Canary Islands and vulnerability to climate change. - Flora-Morphology, Distribution, Functional Ecology of Plants 206: 769-781.

MEIER, M.K. 2008. Checkliste der Laubmoose (Musci) der Schweiz. - Meylania 40:36-40.

MILLER, D.H. \& H.A. MILLER 2007. Entosthodon. - In: Flora of North America. Vol. 27. Mosses, part. 1. New York, Oxford, Oxford Univ. Press: 182-188.

MOYA, J.J., R.M. ROS, J. GUERRA \& M.J. CANO 1995. Weissia papillosissima Laz. (Pottiaceae, Musci), a species new to the European bryophyte flora. -J. Bryol. 18: 493-498.

POCS, T., I. GOIA, G. KIS, S. ORBAN, A. SASS-GYARMATI \& B.O. VAN ZANTEN 2002. Hilpertia velenovskyi (Schiffn.) Zander and other Pottioid mosses (Bryophyta) new to Romania. Studies of the cryptigamic vegetation of loess cliffs, IX. - Contribuții Botanice 37: 13-23.

SABOVLJEVIĆ, M., R. NATCHEVA, G. DIHORU, E. TSAKIRI, S. DRAGIĆEVIĆ, A. ERDAG, \& B. PAPP 2008. Check-list of the mosses of SE Europe. - Phytologia Balcanica 14(2): 207-244.

SÉRGIO, S., M. BRUGUÉS, R.M. ROS., C. GARCIA \& T. LOURO 2006. A new important Mediterranean area for bryophytes in Portugal: Barrancos (Baixo Alentejo). - Bol. Soc. Esp. Briol. 29: 25-33.

SÉRGIO, S. \& S. CARVALHO 2003. Annotated catalogue of Portuguese bryophytes. - Portugaliae Acta Biol. 21: 5-230.

SMITH, A.J.E. 1978. The moss flora of Britain and Ireland.Cambridge, Cambridge Univ. Press: 706 pp.

SOTIAUX, A., A. PIOLI, A. ROYAUD, R. SCHUMACKER \& A. VANDERPOORTEN 2007. A checklist of the bryophytes of Corsica (France): new records and a review of the literature. -J. Bryol. 29: 41-53.

WERNER, O., R.M. ROS \& M. GRUNDMANN 2005. Molecular phylogeny of Trichostomoideae (Pottiaceae, Bryophyta) based on nrITS sequence data. - Taxon 54: 361-368. 